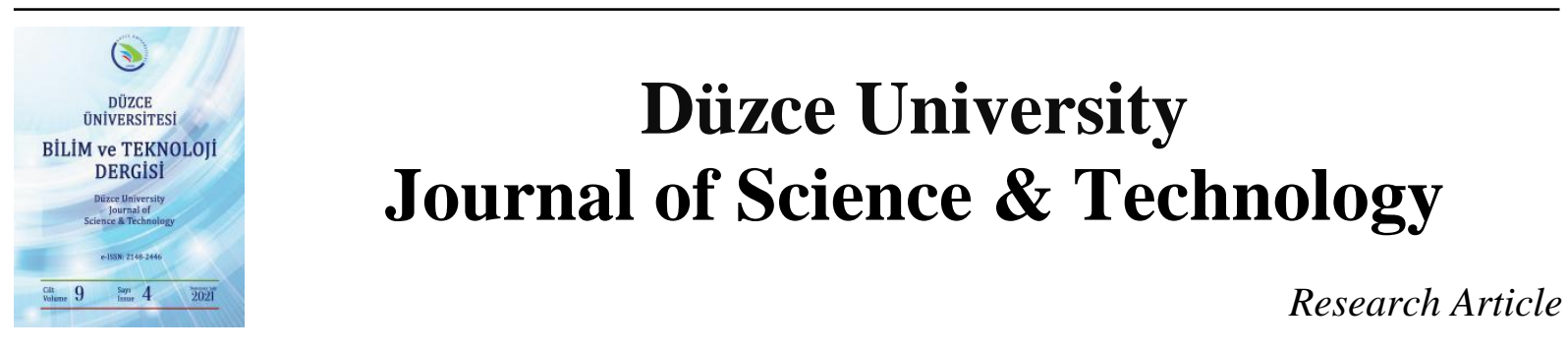

\section{The Effects of Steel Core Imperfection, Gap Size and Friction Coefficient on the Behavior of All-Steel Buckling Restrained Braces}

\author{
DYasin Onuralp ÖZKILIÇa,* \\ ${ }^{a}$ Department of Civil Engineering, Faculty of Engineering, Necmettin Erbakan University, Konya, TURKEY \\ *Corresponding author's e-mail address:yozkilic@erbakan.edu.tr \\ DOI:10.29130/dubited.843214
}

\begin{abstract}
Buckling restrained braces (BRBs) which are generally composed of a steel core and a encasing(buckling restrainers) are utilized to resist lateral forces in high seismic regions since BRBs exhibit high energy dissipation capacity, ductility and stiffness. The steel core carries both compressive and tensile forces. During the compression, the core starts buckling and the encasing tries to prevent this buckling. However, due to the unbonding layer/gap between the encasing and steel core, the steel core eventually buckles and contacts with the encasing. Buckling phenomenon is also associated with the initial imperfection and gap size. In this study, the effects of the initial imperfectionof steel core, gap size (1-5 mm)and friction coefficient (0.01-0.5)between the encasing and steel core on the behavior of BRBs are investigated. Pursuant to this goal, numerical analyses using a finite element tool ABAQUS were conducted. A total of 19 numerical models were developed and monotonically loaded. Initial imperfection was implemented to the models using buckling mode shapes. The results revealed that increasing gap size leads to a reduction in load-carrying capacity. It is recommended to keep gap sizes between 1 and $2 \mathrm{~mm}$. On the other hand, initial imperfection does not significantly affect load-carrying capacity and global behavior. However, it was also observed that the fluctuations in load increase as the amplitude of the mode shape and gap size increase. Moreover, the friction coefficient should be kept between 0.01 and 0.05 ; otherwise, undesired behaviors can be observed.
\end{abstract}

Keywords:Buckling restrained braces, ABAQUS, Buckling, Imperfection, Gap, Friction coefficient, Steel core.

\section{Çelik Çekirdek Kusurunun, Boșluk Boyutunun ve Sürtünme Katsayısının Tamamı Çelik Burkulması Önlenmiş Çaprazların Davranıșına Etkileri}

\begin{abstract}
ÖZ
Burkulması önlenmiş çaprazlar (BÖÇ'ler), genellikle bir çelik çekirdekten ve bir burkulmayı önleyen ortamdan oluşan, yüksek enerji sönümleme kapasiteleri, süneklik ve rijitlik sergiledikleri için, yüksek sismik bölgelerde yanal kuvvetlere direnmek için kullanılır. Çelik çekirdek hem basınç hem de çekme kuvvetlerini taşır. Basınç sırasında çekirdek burkulmaya başlar ve burkulmayı önleyen ortam bu burkulmayı önlemeye çalışır. Bununla birlikte, enkesit ve çelik çekirdek arasındaki boşluk nedeniyle, çelik çekirdek sonunda burkulur. Burkulma fenomeni ayrıca başlangıç kusuru ve sürtünmesiz yüzey/boşluk boyutu ile de ilişkilidir. Bu çalışmada, çelik çekirdeğin başlangıç kusurunun, boşluk boyutunun (1-5 mm) ve sürtünme katsayısının (0.01-0.5) BÖÇ'lerin davranışı üzerindeki etkileri araştırılmıştır. Bu amaç doğrultusunda sonlu elemanlar aracı ABAQUS kullanılarak numerik analizler yapılmıştır. Toplam 19 sayısal model geliştirilmiştir ve tekdüze yüklenmiştir. İlk kusur,
\end{abstract}


burkulma mod şekilleri kullanılarak modellere uygulandı. Sonuçlar, boşluk boyutu artıkça yük taşıma kapasitesinde azalmaya sebep olduğunu ortaya koymuștur. Boşluk boyutunun 1 ile $2 \mathrm{~mm}$ arasında tutulması önerilmiştir. Diğer bir yandan, ilk kusurun yük taşıma kapasitesini ve genel davranışı etkilememiştir. Ancak mod şeklinin ölçeği ve boşluk boyutu arttıkça yükteki dalgalanmaların da arttığı görülmüştür. Ayrıca, sürtünme kaysayısı 0.01 ile 0.05 arasında tutulmalıdır yoksa istenmeyen davranışlar gözlemlenebilir.

Anahtar Kelimeler:Burkulması önlenmiş̧ çaprazlar, ABAQUS, Burkulma, Kusur, Boşluk, Sürtünme katsaylsı, Çelik çekirdek.

\section{INTRODUCTION}

Lateral resisting systems are desired to have high rigidity under wind and seismic loadings [1]. Buckling Restrained Braces (BRBs) are one of the lateral resisting systems which are designed to resist lateral force during a severe seismic event. Unlike conventional braces such as concentrically braced frames, they exhibited stable hysteresis behavior which leads to high energy dissipation capacity, ductility, and stiffness. This behavior is achieved by yielding under both tension and compression.

BRBs, which are sort of metallic dampers, display a balanced hysteretic behavior by axial yielding under reversed cyclic tension and compression forces during major earthquakes. Frames incorporating BRBs could also be used with the purpose of seismic retrofitting to increase lateral stiffness and strength of existing reinforced concrete (RC) or steel buildings. Recently, some further applications are being made in Japan and the USA, particularly as ductile energy dissipating end diaphragms in steel bridges. Approximate symmetric behavior of BRBs under tension and compression and their feature of not causing any degradation in terms of stiffness and strength as well as obtaining stable hysteretic curves expand their area of use. Furthermore, when compared to other alternative seismic energy dissipation systems, BRBs have several advantages such as easy replacement following an earthquake (if needed), easy construction with relatively low cost and simple end connection details [2-4].

Buckling restrained brace includes a core and an encasing. Figure 1 demonstratesa typical buckling restrained brace. A typical buckling restrained brace can be divided into three segments: restrained yielding segment (restrained plastic zone), restrained non-yielding segment (restrained elastic zone), unrestrained non-yielding segment (unrestrained elastic zone). These segments are illustrated in Figure 1. The unrestrained non-yielding segment is used to connect a buckling restrained brace to a frame. The restrained yielding segment is composed of a core and an encasing. Restrained non-yielding is designed to show elastic behavior [5]. Generally, the core element is made of steel material. For the encasing, concrete encasing [6-8] or all-steel encasing $[9,10]$ is generally preferred.

As it is seen in Figure 1, unbonding material or a gap is provided between the encasing and core element. Different materials such as thin rubber, polyethylene, silicone grease, and tape strip have been tested for this part [11]. The main aim to utilize unbonding material is to eliminate or minimize axial force transfer between the encasing and core element. Instead of using unbonding material, a gap is also provided as an alternative to the unbonding material.

Due to this gap, core elements buckle under compressive force. As the gap size increase, the load carrying capacity of buckling restrained braces reduces. Moreover, increasing the gap size may lead to a reduction in the low-cycle fatigue life of buckling restrained braces [11].

A gap size of $2 \mathrm{~mm}$ between the steel core and concrete was introduced by Guo et al.[12]. Chou and Chen [13] utilized a gap size of $1.5 \mathrm{~mm}$ between the steel core and concrete. Avc1-Karatas et al.[2] used $1.5 \mathrm{~mm}$ for gap size between aluminum/steel core and concrete encasing. A gap size of $1.5 \mathrm{~mm}$ between the steel core and steel encasing was utilized by Guo et al.[9]. AlHamaydeh et al. [14] adopted $2.54 \mathrm{~mm}$ for the gap size between the steel core and concrete encasing. Bozkurt and Topkaya 
[10] utilized two different gap sizes of $1 \mathrm{~mm}$ and $3 \mathrm{~mm}$ including the thickness of teflon pad for the steel core and steel encasing. Heidary-Torkamani et al. [15] utilized a gap size of $6 \mathrm{~mm}$ between the tubed steel core and tubed steel encasing.

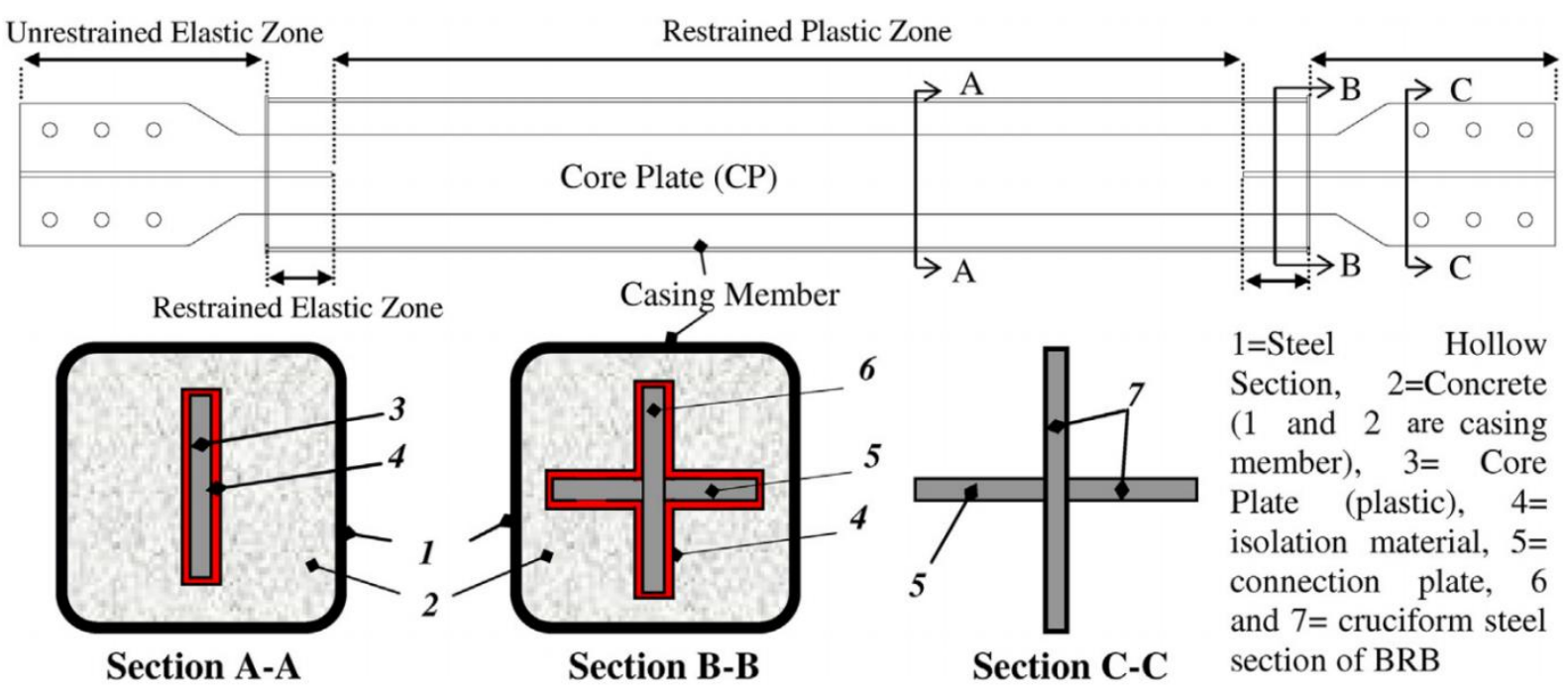

Figure 1.Typical buckling restrained brace [8]

In the literature, limited studies $[6,9,12-18]$ are available on numerical modeling of BRBs. The reason for this can be attributed to the complexity of modeling interaction between the steel core and encasing, which leads to significant convergence problems and computational cost. The interaction occurs whenever the steel core buckles and contacts the encasing. Therefore, monotonic loading [13, 18] or one cycle of cycling loading [14] are also preferred for a parametric study of BRBs in order to reduce the convergence problems and computational cost. If the bolted connections were designed as elastic during the experiments, the interaction of these connections may notbe included in the model in order to simplify further the numerical models $[6,13,18]$.

For numerical modeling, different friction coefficients were adopted by the researchers. Guo et al.[12] and Cao et al. [17] utilized a friction coefficient of 0.1 for the interaction between the steel core and concrete encasing. Avci-Karatas et al.[16] used a friction coefficient of 0.03 for the interaction between the steel core and concrete encasing where a teflon pad was utilized. Chou and Chen [13] and Heidary-Torkamani et al. [15] selected friction coefficient as 0.1 for the steel core and steel encasing where grease oil was utilized. Guo et al. [9] selected the friction coefficient of the steel core to steel encasing interaction as 0.1.A friction coefficient of 0.05 was utilized by Wang et al. [6] for the interaction between the steel core and concrete encasing.

Initial imperfection should be implemented into numerical models in order to trigger the buckling phenomenon. Initial imperfection can be applied using buckling mode shapes with a predefined amplitude which is generally indicated with the length of the steel core or applying a predefined displacement. Cao et al. [17]simulated the geometrical imperfection of the steel core by combining the first mode (one sin wave) and the third mode (three sine wave) with an amplitude of $1 / 1000$ of the length.The initial imperfection of L/1000 with first mode shape (one sin wave) was adopted by Guo et al.[12], Guo et al.[9], Jiang et al. [18] and Wang et al. [6]. On the other hand, Chou and Chen [13] utilized the first mode (one sin wave) with an amplitude of L/3000 to simulate initial imperfection. AlHamaydeh et al. [14] adopted L/1850 to have slower convergence and less computational efficiency.

In this study, the effects of gap size, initial imperfection and friction coefficient on the behavior of buckling restrained braces are studied. If the provided gap is too small, the core element and encasing can interact which leads to axial force transfer. On the other hand, if the provided gap is too large, then 
the steel core significantly buckles. Therefore, the size of this gap is an important parameter that should be considered in the design of the buckling restrained braces. Other important parametersconsidered in the numerical analyses are initial imperfection and friction coefficient. It is seen in the aforementioned studies that there is no consensus in the literature about the value of gap size, friction coefficient and initial imperfection. Therefore, the effects of these parameters on the behavior of the buckling restrained braces are evaluated in terms of maximum load, energy dissipation capacity and PEEQ.

\section{NUMERICAL STUDY}

Numerical analyses were performed using the finite element modeling tool, ABAQUS with a version of 6.12-1 [19]. ABAQUS is a very reliable finite element software that was preferred by many researchers [20-24].Three-dimensional solid elements were used to construct the numerical model. Numerical models were constructed using an eight-node brick element with reduced integration (C3D8R). Since the non-yielding segment was designed as elastic, coarse mesh size was utilized for the parts in the non-yielding segments. On the other hand, a finer mesh size was adapted for the parts in the yielding segments where deformation and yielding were expected to occur. Moreover, the mesh size of the encasing was chosen to be equal to the steel core since the steel core and encasing exhibit interactions. Therefore, $10 \mathrm{~mm}$ mesh size was selected for the encasing and steel core whereas $50 \mathrm{~mm}$ mesh size was used for the rest of the elements. Moreover, in order to accurately capture the buckling of members, four layers through thickness were recommended[25-27]; therefore, the thickness of steel core was divided into four elements. The detailed mesh configuration is depicted in Figure 2. Numerical models consist of a total of 41018 elements and 70080 nodes.

Both geometric and material nonlinearity was implemented in the model. Bolts, welds and connections were not modeled in order to reduce computational time and to prevent any possible convergence problem. Instead, tie constraint was used to connect the elements. Frictional surfaces may lead to significant convergence problems[27]. Two types of contact forces were introduced to the numerical models: normal contact and tangential frictional forces. The finite sliding surface to surface contact was used for the surface between the encasing and steel core. The friction coefficient was taken as 0.03 for the tangential behavior.Hard contact approach was performed for normal behavior.

Boundary conditions were assigned to the back face of the end-plates. These end-plates were connected to the columns in the experimental study. Therefore, all degrees of freedom were restrained excepted that transitional restraint was released at the end-plate where the loading was applied. MPC constraint was defined to a reference point at the center of the end-plate. The loading was applied to this reference point. Displacement controlled monotonic loading was applied to the models.

Yielding and ultimate loading of the core plate are reported as 373 and $510 \mathrm{MPa}$ for the core plates. Young's modulus and possion's ratio were used $210 \mathrm{GPa}$ and 0.3 , respectively. The experimental study was conducted under cyclic loading. Monotonic loading was preferred for numerical analyses in order to reduce computational cost and convergence problems. With accurate numerical modeling of the material, the results of monotonic numerical modeling can be compared with the results of experimental cyclic loading [28-33]. Therefore, a stabilized material model described in Bozkurt et al. [29] and Özkılıç et al. [28] was utilized herein. Stabilized material model is used to mimic cyclic hardening of steel in the monotonic analyses when the tensile coupon test results are available and cyclic behavior of the steel is absent. 

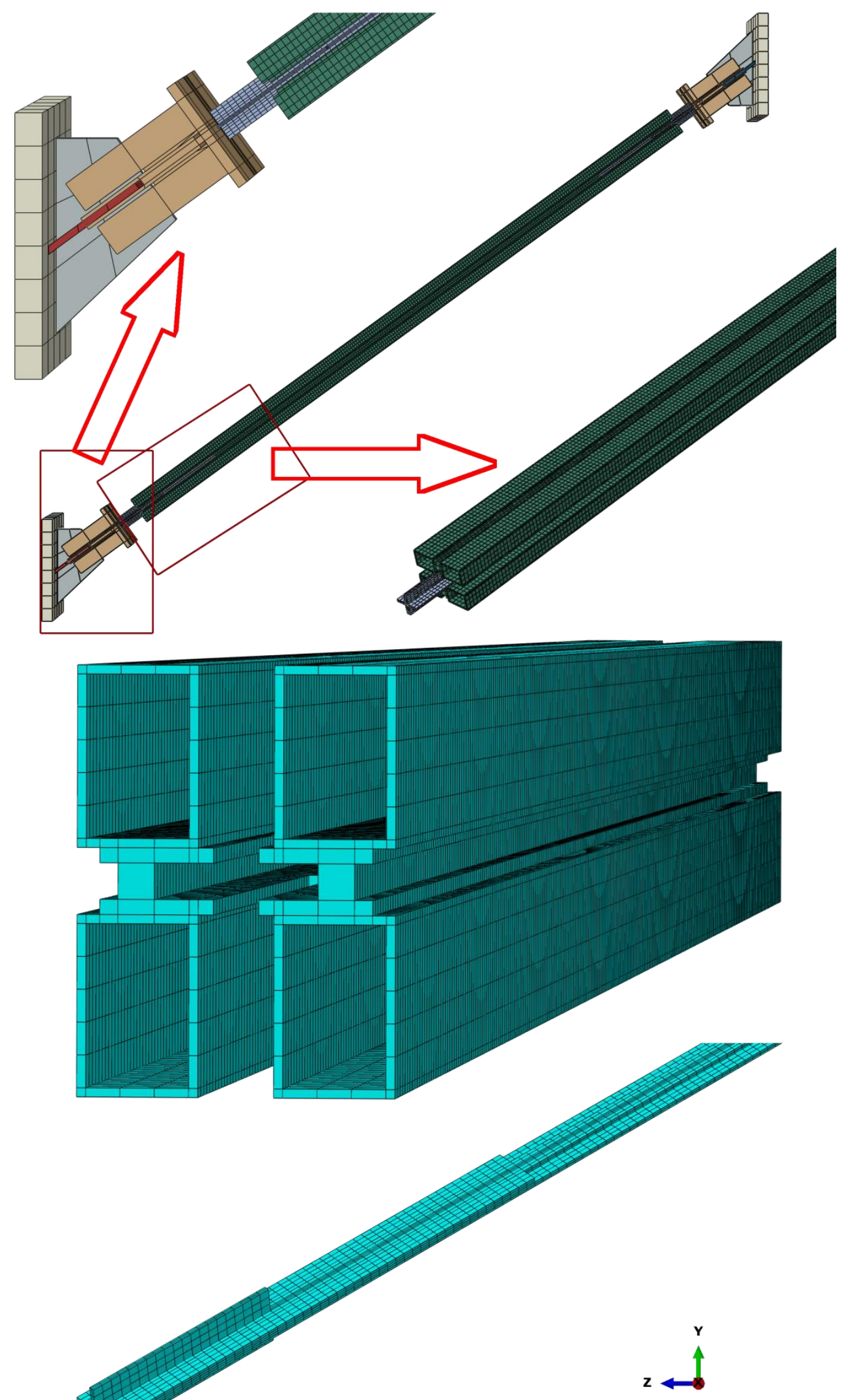

Figure 2. Mesh configuration

The numerical models are compared in terms of PEEQ, $\mathrm{P}_{\max }$ and energy dissipation capacity. PEEQ is the plastic equivalent strain and calculated as ratio of effective plastic strain to yield strain. PEEQ 
measures local plastic strain demand and higher value of PEEQ indicates potential damage and vulnerability[27, 34]. $\mathrm{P}_{\max }$ is the maximum loading observed in the load-displacement curve. Energy dissipation capacity is calculated under the area of the load-displacement curve[35].

For verification model and parametric study, the design of all-steel BRBs developed by Bozkurt et al. [36] was preferred. Bozkurt et al. [36] studied different connection detail on BRBs with welded overlap cores. The details of the sub-assemblage test setup are given in Figure 3. Bozkurt et al. [36] conducted four tests using gusset and pin connection. In this study, the BRB with gusset connections was utilized. The length of the BRB was $3730 \mathrm{~mm}$ and the angle was 36.5 degrees. Loading was applied through a column. A cyclic loading recommended by AISC Seismic provisions for Structural Steel Buildings [37] was exposed to the specimens.
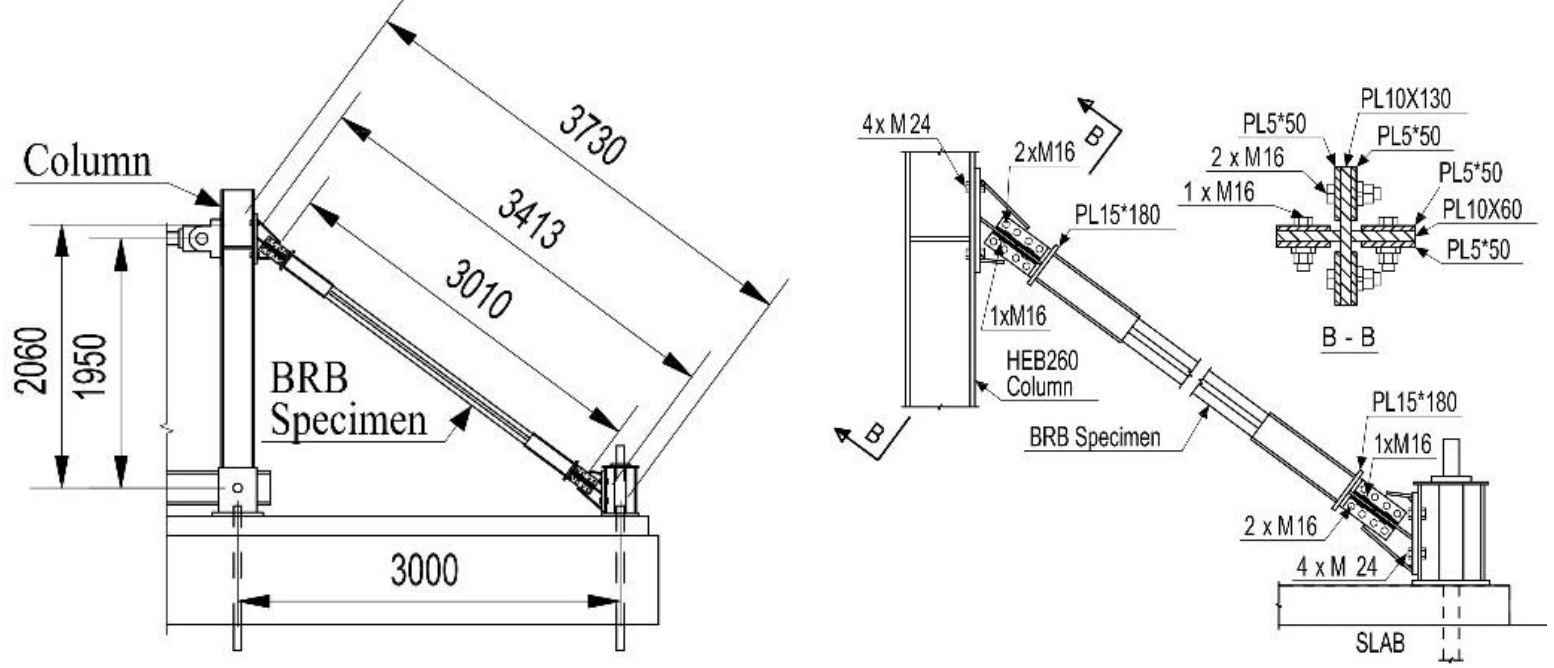

* All Dimensions are in mm.

Figure 3. Details of sub-assemblage test setup [36]

Figure 4 demonstrates the cross-section of encasing and steel core. A total of $2 \mathrm{~mm}$ gap is provided between the steel core and encasing. Teflon is used to reduce friction between steel and encasing.
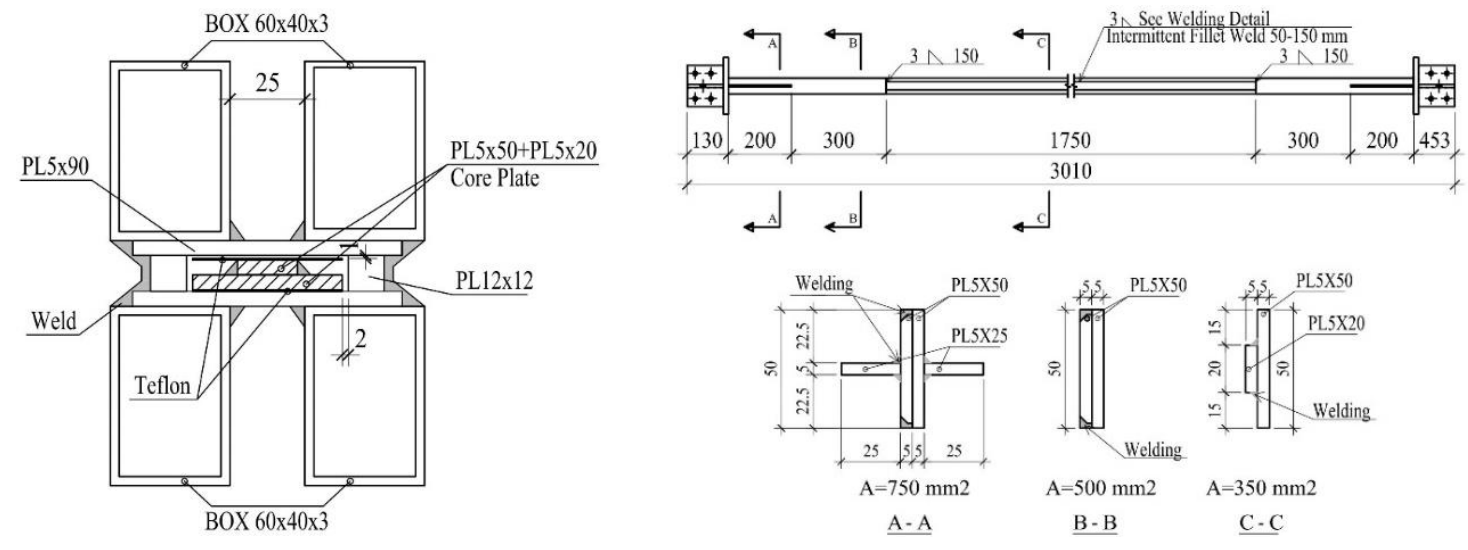

Figure 4. Details of steel core and encasing [36]

Initial imperfection was implemented to numerical models using *IMPERFECTION option which is available in the library of ABAQUS. In order to determine mode shapes, eigen-value analyses were conducted. The first five-mode shapes were recorded (Figure 5). In the verification model, the first mode shape (one sin wave) with an amplitude of $L / 7000(0.25 \mathrm{~mm})$, where $\mathrm{L}$ is the length of the yielding segments, was utilized. 

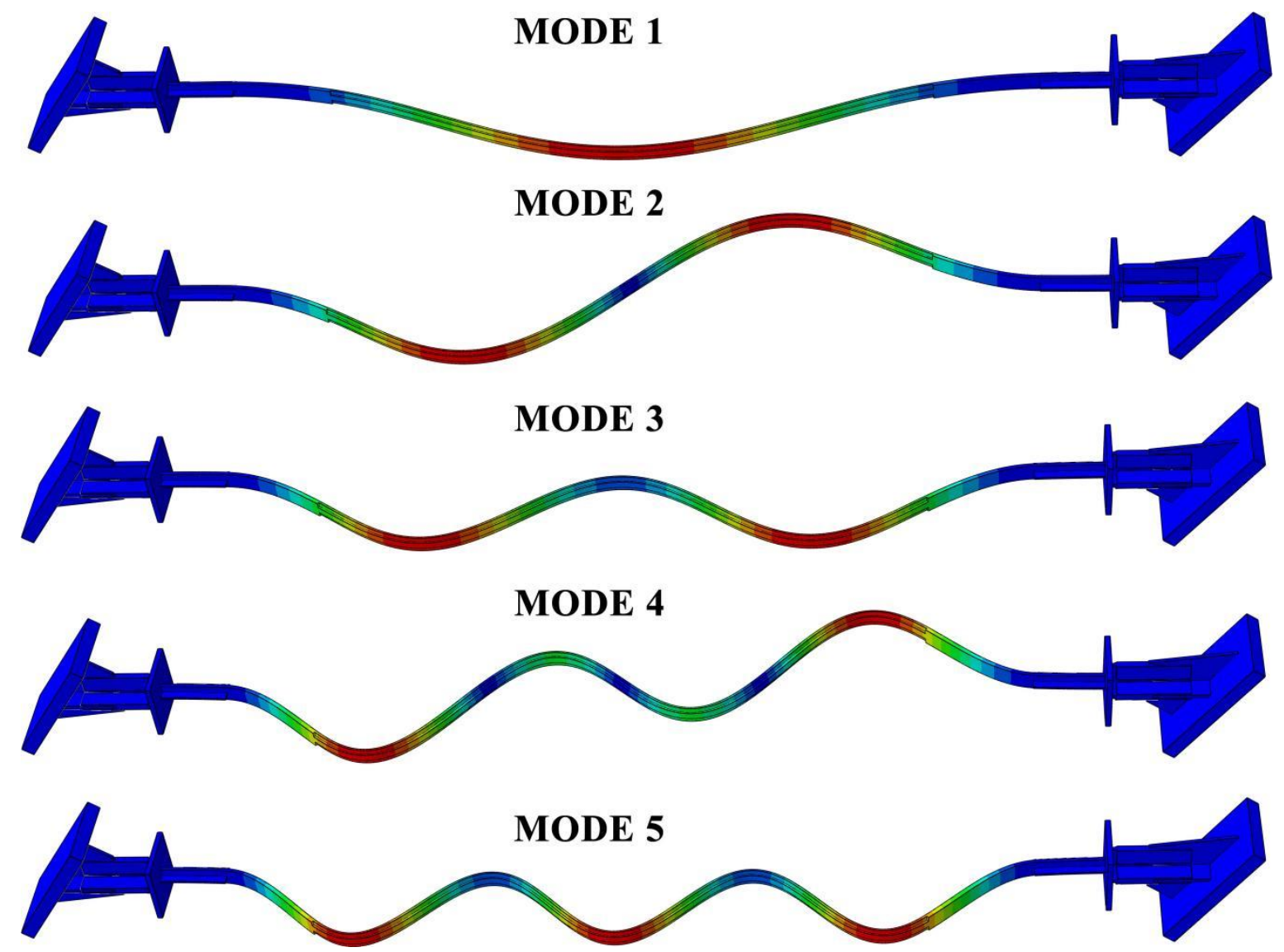

Figure 5. Mode shapes

Table 1. Properties of models

\begin{tabular}{ccccc}
\hline Model & Gap Size & $\begin{array}{c}\text { Friction } \\
\text { Coefficient }\end{array}$ & Mode Shape & Amplitude \\
\hline Model 1 & 1 & 0.03 & Mode Shape 1 & $\mathrm{L} / 7000$ \\
Model 2 & 2 & 0.03 & Mode Shape 1 & $\mathrm{L} / 7000$ \\
Model 3 & 3 & 0.03 & Mode Shape 1 & $\mathrm{L} / 7000$ \\
Model 4 & 4 & 0.03 & Mode Shape 1 & $\mathrm{L} / 7000$ \\
Model 5 & 5 & 0.03 & Mode Shape 1 & $\mathrm{L} / 7000$ \\
Model 6 & 2 & 0.03 & Mode Shape 1 & $\mathrm{L} / 3500$ \\
Model 7 & 2 & 0.03 & Mode Shape 1 & $\mathrm{L} / 1750$ \\
Model 8 & 2 & 0.03 & Mode Shape 5 & $\mathrm{L} / 3500$ \\
Model 9 & 2 & 0.03 & Mode Shape 5 & $\mathrm{L} / 1750$ \\
Model 10 & 2 & 0.03 & Mode Shape 1+ 5 & $\mathrm{L} / 1750$ \\
Model 11 & 2 & 0.01 & Mode Shape 1 & $\mathrm{L} / 7000$ \\
Model 12 & 2 & 0.02 & Mode Shape 1 & $\mathrm{L} / 7000$ \\
Model 13 & 2 & 0.04 & Mode Shape 1 & $\mathrm{L} / 7000$ \\
Model 14 & 2 & 0.05 & Mode Shape 1 & $\mathrm{L} / 7000$ \\
Model 15 & 2 & 0.1 & Mode Shape 1 & $\mathrm{L} / 7000$ \\
Model 16 & 2 & 0.2 & Mode Shape 1 & $\mathrm{L} / 7000$ \\
Model 17 & 2 & 0.3 & Mode Shape 1 & $\mathrm{L} / 7000$ \\
Model 18 & 2 & 0.4 & Mode Shape 1 & $\mathrm{L} / 7000$ \\
Model 19 & 2 & 0.5 & Mode Shape 1 & $\mathrm{L} / 7000$ \\
\hline
\end{tabular}


A total of 19 numerical models were developed for the parametric study. Table 1 demonstrates the properties of the numerical models. Models 1-5, Models 6-10 and Models 11-19 were designed to investigate the effects of gap size, mode shapes with different amplitude and friction coefficient, respectively.

\section{RESULTS AND DISCUSSION}

\section{A. VERIFICATION MODEL}

The comparison of numerical results and experimental findings in terms of hysteresis behavior is given inFigure 6. The verification model revealed that the finite element model is able to mimic the load-displacement curve of the experimental result monotonically and gives slightly stiffer results than the experimental findings. It can be said that the developed numerical models with described assumptions are capable of predicting experimental results.

The deformed shapes of experimental and numerical study are compared in Figure 7. It is seen that the numerical model simulated buckling of the steel core due to the provided gap. Similar buckling at failure was also observed in the experimental study. The deformed shapes were only compared at the end of the experiment since the deformation of the steel core could not be observed during the experiments due to the steel encasing. Therefore, it can be concluded that the assumed model can be used to investigate the effect of the gap size and initial imperfection.

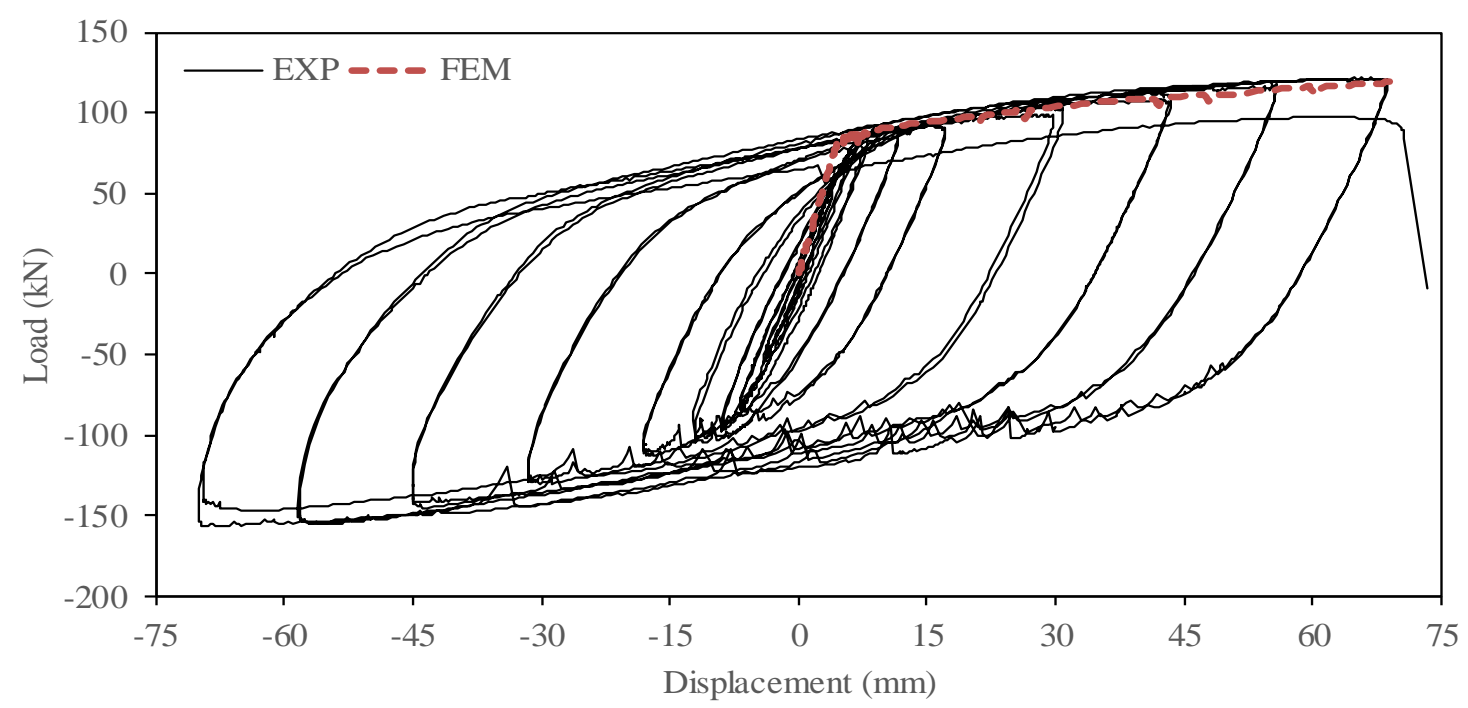

Figure 6. The comparison of numerical and experimental results

Figure 8 illustrates the deformed shapes of the specimens at the displacement values of $5 \mathrm{~mm}, 10 \mathrm{~mm}$, $30 \mathrm{~mm}, 50 \mathrm{~mm}$ and $70 \mathrm{~mm}$. It is seen that almost no PEEQ is observed up to $10 \mathrm{~mm}$. After $10 \mathrm{~mm}$, the value of PEEQ distribution significantly increased. On the other hand, initial imperfection of one sine wave is observed in U1 distribution at $5 \mathrm{~mm}$, where $\mathrm{U} 1$ indicates the displacement in $-\mathrm{X}$ direction shown in Figure 8. It is seen that buckling was initiated at a displacement value of $10 \mathrm{~mm}$. The number of buckled waves increases as the value of displacement increases. Moreover, the shortening of the steel core due to compression can be seen in Figure 8. 

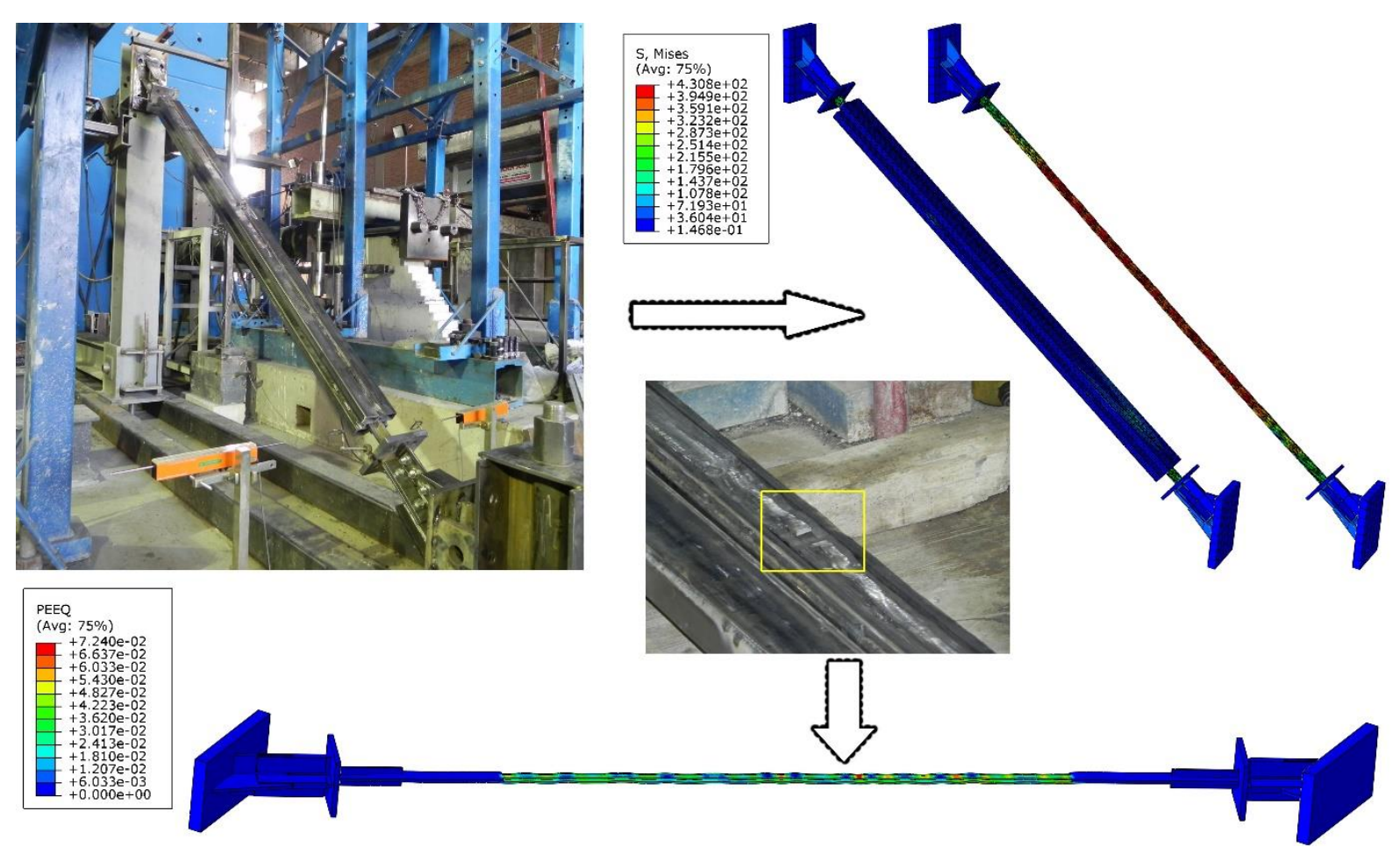

Figure 7.Deformed shapes
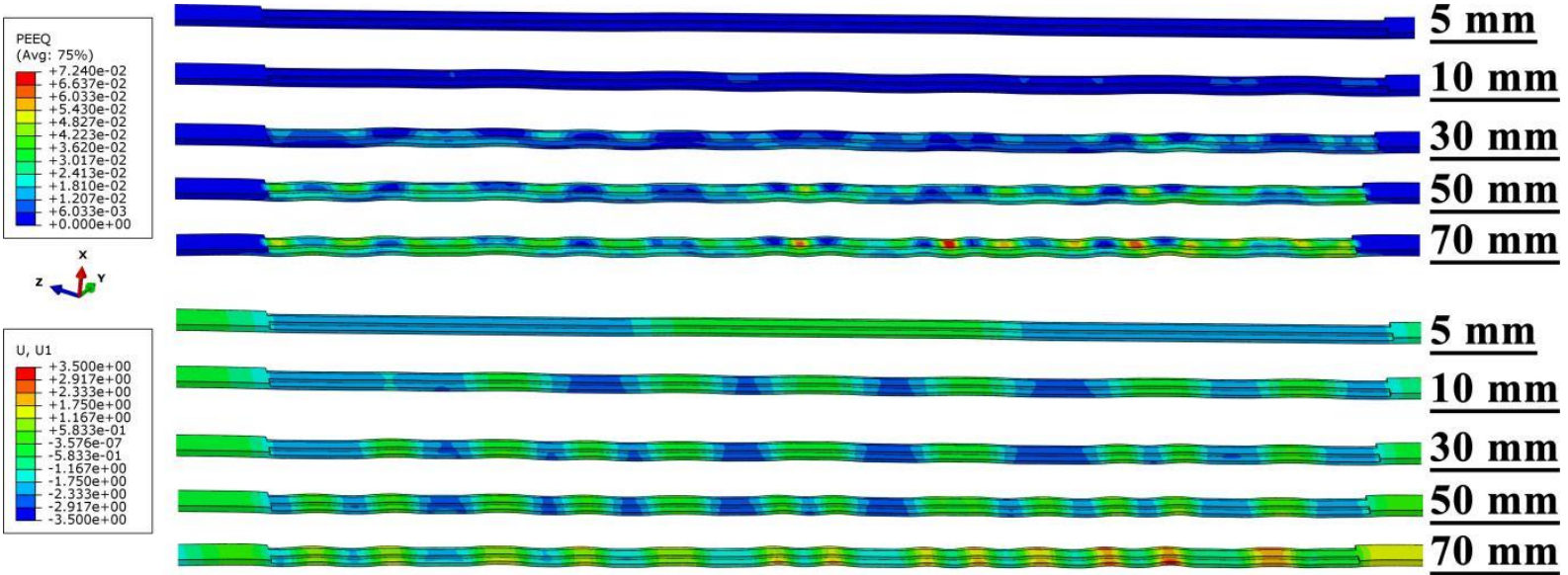

Figure 8. Progress of PEEQ and U1distributions

\section{B. THE EFFECTS OF GAP SIZE}

Five numerical models having the same boundary conditions, material models, dimensions were constructed. The numerical models have the same properties as the verification model, except that different gap sizes were adopted. Total gap sizes of $1 \mathrm{~mm}, 2 \mathrm{~mm}, 3 \mathrm{~mm}, 4 \mathrm{~mm}$, and $5 \mathrm{~mm}$ were selected. In the experimental study, a total gap size of $2 \mathrm{~mm}$, indicating $1 \mathrm{~mm}$ gap size for each side, was utilized. All models were subjected to monotonic loading up to the displacement of $70 \mathrm{~mm}$.

Load-displacement curves of numerical models are shown in Figure 9. Table 2 demonstrates loading capacity, energy dissipation capacity and maximum PEEQ value of the models. It is observed that increasing gap size results in decreases in maximum loading and energy dissipation capacity. $10 \%$ and $14 \%$ differences of maximum load and energy dissipation capacityare observed between numerical models with a gap size of $1 \mathrm{~mm}$ and $5 \mathrm{~mm}$, respectively. More importantly is that increasing gap size leads to fluctuations in load-displacement curves. These fluctuations were also observed in the 
experimental study (Figure 6). As the gap size increases, the fluctuations increase. For the model with a gap size of $5 \mathrm{~mm}$, these fluctuations decreased loading up to 22\%. This ratio modifies to $3 \%$ when the gap size is reduced to $1 \mathrm{~mm}$. Moreover, maximum value of PEEQ observed at the models increases as the gap size increases, which indicates that the model with a gap size of $5 \mathrm{~mm}$ is most vulnerable to the damage and the model with a gap size of $1 \mathrm{~mm}$ is least susceptible to the damage.

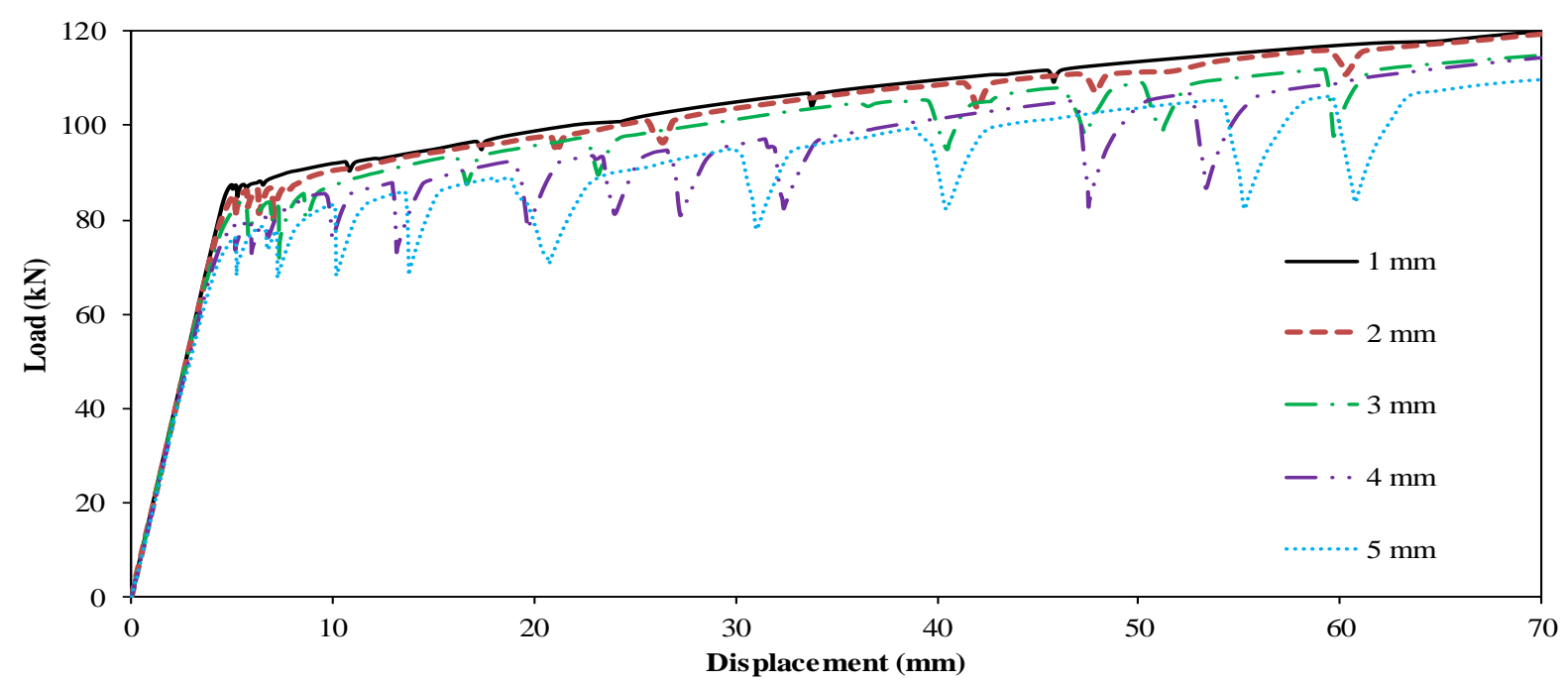

Figure 9. Comparison of load-displacement curves of the models having different gap size

Table 2.The results of models with different gap sizes

\begin{tabular}{ccccc}
\hline Model & Gap Size $(\mathbf{m m})$ & $\mathbf{P}_{\max }(\mathbf{k N})$ & Energy $(\mathbf{J})$ & PEEQ \\
\hline Model 1 & 1 & 120.1 & 7170 & 0.054 \\
Model 2 & 2 & 119.4 & 7064 & 0.072 \\
Model 3 & 3 & 114.9 & 6829 & 0.093 \\
Model 4 & 4 & 114.4 & 6541 & 0.097 \\
Model 5 & 5 & 109.7 & 6287 & 0.116 \\
\hline
\end{tabular}

\section{THE EFFECTS OF INITIAL IMPERFECTION}

Six numerical models having the same assumptions used in the verification model were constructed. The difference between these models is only initial imperfection. As discussed in the aforementioned studies, the initial imperfection shape was mostly considered as a single sine wave (Mode 1) and also it is seen that three sine waves (Mode 5) was also utilized for the initial imperfection.Therefore, Mode shape 1 (single sine wave), Mode shape 5 (three sine wave) and the combination of these mode shapes were considered as the parameters for the parametric study. Moreover, different amplitudes of sine waves were considered. The maximum amplitude is L/1750 (approximately $1 \mathrm{~mm}$ ) is equal to one side of the gap size.One should be careful while selecting the imperfection amplitude. If the imperfection of the steel core exceedsthe gap size, initial convergence problems may arise.

The results of the parametric study are demonstrated in Figure 10. Table 3 demonstrates the loading capacity, energy dissipation capacity and maximum PEEQ value of the models.It is observed that all numerical models exhibited almost the same load-carrying capacity. The difference between numerical models is the fluctuations that occurred in the loading, which resulted in a difference in energy dissipation capacities. A maximum 3\% difference in energy dissipation capacity was observed. It is seen in Figure 10 that as the amplitude of the mode shape increases, the fluctuations in the loaddisplacement curves increase. Moreover, the value of PEEQ increases as the amplitude of the mode shape increases. However, it can be concluded that the change in loading capacity, energy dissipation capacity and PEEQ is insignificant. 
Table 3.The results of models having differentmode shapes and amplitudes

\begin{tabular}{cccccc}
\hline Model & Mode Shape & Amplitude & P $_{\max }(\mathbf{k N})$ & Energy $(\mathbf{J})$ & PEEQ \\
\hline Model 2 & Mode Shape 1 & L/7000 & 119.4 & 7064 & 0.072 \\
Model 6 & Mode Shape 1 & L/3500 & 119.4 & 6978 & 0.073 \\
Model 7 & Mode Shape 1 & L/1750 & 118.9 & 6855 & 0.075 \\
Model 8 & Mode Shape 5 & L/3500 & 119.4 & 7023 & 0.072 \\
Model 9 & Mode Shape 5 & L/1750 & 118.6 & 6986 & 0.078 \\
Model 10 & Mode Shape 1 + 5 & L/1750 & 119.9 & 6870 & 0.073 \\
\hline
\end{tabular}
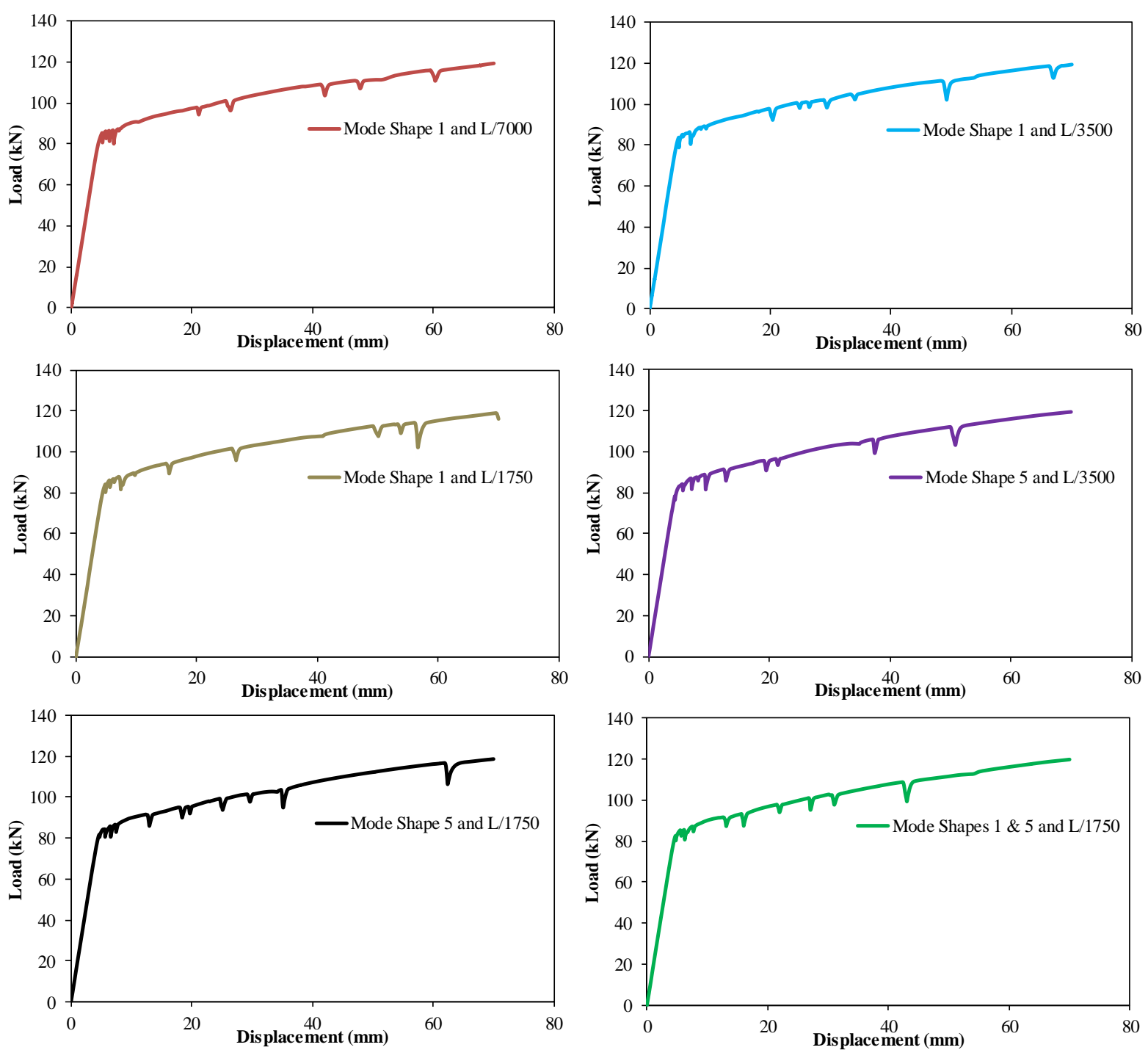

Figure 10. Comparison of load-displacement curves for the models having different mode shapes and amplitudes

\section{THE EFFECTS OF FRICTION COEFFICIENT}

The results of ten numerical models having different friction coefficients are compared in Figure 11. The results in terms of the maximum loading, energy dissipation capacity and PEEQ are given in Table 4. It should be noted that significant convergence problems were encountered in the models having friction coefficients higher than 0.10 . In order to circumvent the convergence problems, several attempts were tried by changing the friction coefficient gradually with \pm 0.005 . For example, when the 
model having thefriction coefficient of 0.5 was not converged, then the models having friction coefficients in order of $0.495,0.505,0.49,0.51,0.485,0.515,0.48$ and 0.52 were analyzed until the model converges. The converged friction coefficients are given in Table 4. Furthermore, as the friction coefficient increases, computational time increases.

It is seen that the results of the models having friction coefficient below 0.1 are similar in terms of maximum loading, energy dissipation capacity and PEEQ. On the contrary, the behavior of the models significantly changes when the friction coefficient is higher than 0.1. Although energy dissipation and load capacities of the models having friction coefficient equal and higher than 0.1 are significantly higher than those of the models having friction coefficient below 0.1, PEEQ values of former ones are significantly high. This indicates that these models are prone to failure in earlier cycles. Moreover, it is seen in Figure 12 that undesirable behavior is observed in the models having friction coefficients equal and higher than 0.1. PEEQ distributions are concentrated in the restrained elastic zone which should be designed elastic during the cyclic loading. Therefore, the friction coefficient equal and higher than 0.1 should be avoided and necessary precautions should be taken in the design of BRBs. Teflon pad or grease oil can be utilized between the steel core and encasing in order to minimize the friction coefficient.

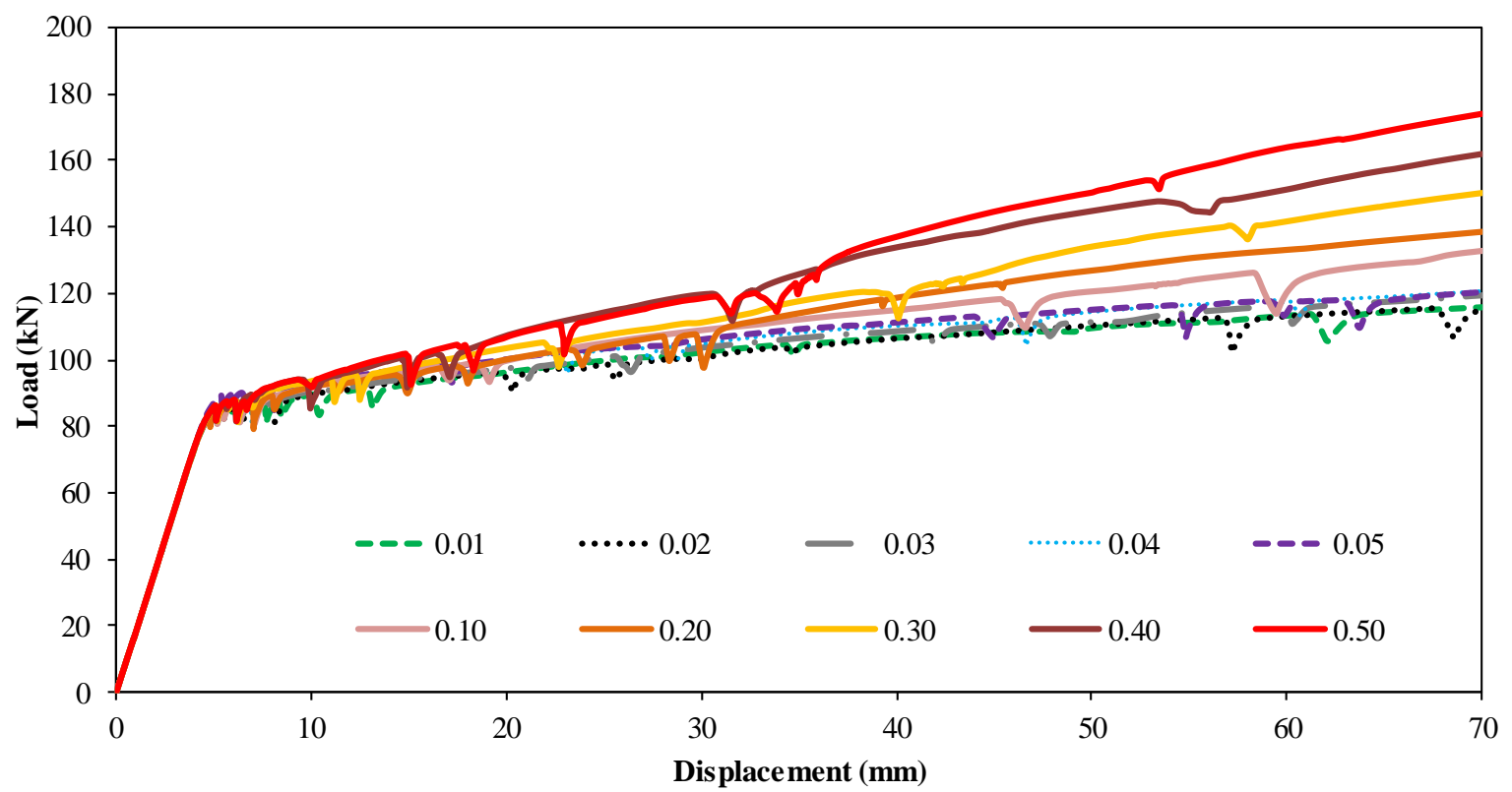

Figure 11. Comparison of load-displacement curves of the models having a different friction coefficient

Table 4. The results of models with the different friction coefficient

\begin{tabular}{cccccc}
\hline Model & $\begin{array}{c}\text { Friction Coefficient } \\
(\mu)\end{array}$ & $\begin{array}{c}\text { Converged } \\
(\mu)\end{array}$ & $\begin{array}{c}\mathbf{P}_{\max } \\
(k N)\end{array}$ & $\begin{array}{c}\text { Energy } \\
(J)\end{array}$ & PEEQ \\
\hline Model 2 & 0.03 & 0.03 & 119.4 & 7064 & 0.072 \\
Model 11 & 0.01 & 0.01 & 118.5 & 6947 & 0.071 \\
Model 12 & 0.02 & 0.02 & 118.9 & 6959 & 0.072 \\
Model 13 & 0.04 & 0.04 & 120.2 & 7073 & 0.073 \\
Model 14 & 0.05 & 0.05 & 121.4 & 7078 & 0.073 \\
Model 15 & 0.10 & 0.10 & 132.7 & 7424 & 0.121 \\
Model 16 & 0.20 & 0.195 & 138.5 & 7677 & 0.136 \\
Model 17 & 0.30 & 0.295 & 150.2 & 7998 & 0.157 \\
Model 18 & 0.40 & 0.415 & 161.9 & 8351 & 0.162 \\
Model 19 & 0.50 & 0.520 & 174.0 & 8756 & 0.171 \\
\hline
\end{tabular}




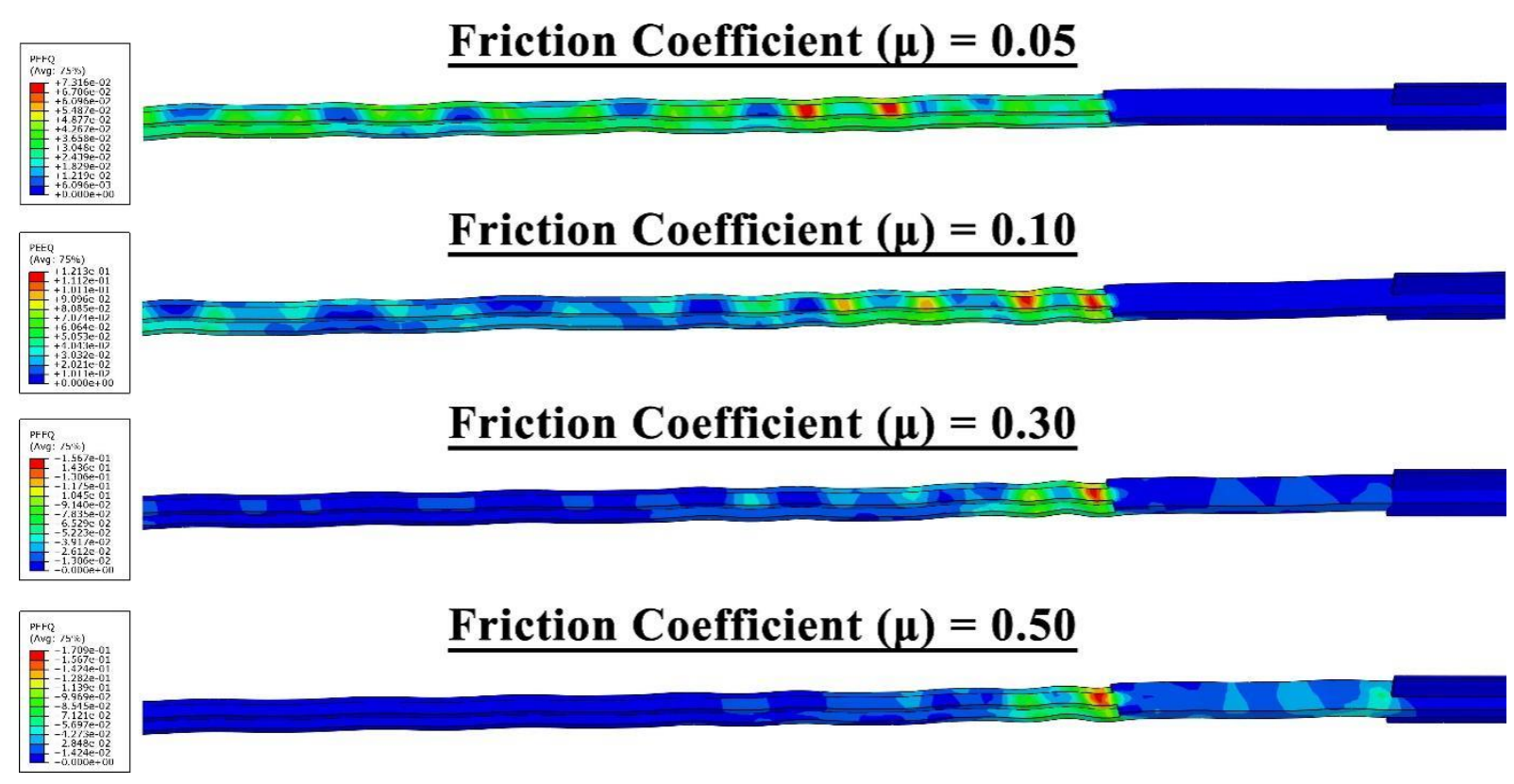

Figure 12. PEEQ distributions of the models having friction coefficient of $0.05,0.1,0.3$ and 0.5

\section{CONCLUSION}

The steel core is one of the most important elements in BRBs, which is directly related to the capacity of BRBs. The steel core yields under both tension and compression. Due to the gap, steel core buckles under compression and buckling are associated with initial imperfection and gap size between the encasing and steel core. The friction coefficient is alsoan important parameter that influences the axial load transfer between the steel core and encasing. A total of 19 numerical models were constructed for the parametric study using finite element software (ABAQUS) in order to examine the effects of gap size, initial imperfection and friction coefficient on the behavior of BRBs. The followings can be drawn based on the numerical study:

- The gap size between the steel core and encasing is investigated using five numerical models. The results revealed that increasing gap size leads to a significant decrease in loading and energy dissipation capacities. Moreover, the fluctuations are more pronounced in the models with larger gap sizes. These fluctuations may significantly affect low-cycle fatigue life. Therefore, it is recommended to use the minimum gap size as possible. However, one should be careful to avoid any load transfer between the encasing and steel core. On the other hand, Bozkurt and Topkaya [10] reported that the specimen having a gap size of $1 \mathrm{~mm}$ exhibited significantly better performance than that of the specimen having a gap size of $3 \mathrm{~mm}$. Therefore, the gap size of 1-2 mm between the steel core and steel encasing is recommended, provided that proper unbonding materials are utilized.

- Six numerical models having different initial imperfection are studied. The results revealed that initial imperfection has almost no effect onthe load-carrying capacity, energy dissipation capacity and PEEQ. However, the fluctuations in the load-displacement curves increase as the amplitude of the mode shape increases. This study was conducted under monotonic loading; therefore, these fluctuations are expected to increase under cyclic loading.

- When buckling mode shapes are utilized for initial imperfection, the amplitude of the mode shape should be less than the gap size of each side; otherwise, the model will lead to initial convergence problems. Furthermore, increasing initial imperfection increases computational cost and leads to convergence problems, which were also reported in[14, 15]. 
- The effects of friction coefficient were investigated with 10 models having friction coefficients between 0.01 and 0.50 . The results showed that the models with friction coefficients between 0.01 and 0.05 exhibited stable yielding along the steel core and similar performance in terms of loading capacity, energy dissipation capacity and PEEQ distribution. On the contrary, the models having friction coefficients equal and higher than 0.10 exhibited undesirable behavior and significantly increased loading capacity. Yi [38]also reported that friction coefficient higher than 0.15 significantly affects the compression behavior of BRBs. Therefore, it can be concluded that the friction coefficient between 0.03 and 0.05 is convenient for the interaction of the steel core and steel encasing when an adequate unbonding material is provided.

- Since unstable behavior is not desired in the design of BRBs, the friction coefficient higher than 0.10 should be avoided. Necessary precautions should be taken in the design of BRBs.Based on the experimental studies ofChou and Chen [13], Heidary-Torkamani et al. [15] and Bozkurt and Topkaya [10], grease oil and teflon pad can be utilized between the steel core and encasing for all-steel BRBs.

- Significant convergence problems occurred in the models having a friction coefficient higher than 0.1. Moreover, computational cost increases as the friction coefficient increases.

\section{REFERENCES}

[1] M. E. Kural, Ö. Zeybek, and M. Seçer, "Çelik Yapi Sistemlerinde İkinci Mertebe Analiz Yöntemlerinin İncelenmesi," Dokuz Eylül Üniversitesi Mühendislik Fakültesi Fen ve Mühendislik Dergisi, vol. 13, no. 2, pp. 75-87, 2011.

[2] C. Avci-Karatas, O. C. Celik, and C. Yalcin, "Experimental investigation of aluminum alloy and steel core buckling restrained braces (BRBs)," International Journal of Steel Structures, vol. 18 , no. 2, pp. 650-673, 2018.

[3] C. Avci-Karatas and O. C. Celik, "Çelik Çekirdekli Burkulması Önlenmiş Çaprazların (BÖÇ) tasarımı, üretimi ve deneysel incelenmesi," Teknik Dergi, c. 30, s. 1, ss. 8861-8886, 2019.

[4] C. Avci-Karatas and O. C. Celik, "Design, fabrication, and cyclic behavior of aluminum alloy core buckling restrained braces (BRBs)," Pamukkale University Journal of Engineering Sciences, vol. 23, no. 6, pp. 659-670, 2017.

[5] Y. O. Özkılıç, M. B. Bozkurt, and C. Topkaya, "Evaluation of seismic response factors for BRBFs using FEMA P695 methodology," Journal of Constructional Steel Research, vol. 151, pp. 41 57, 2018.

[6] J. Wang, B. Li, C. Chou, and L. Chen, "Cyclic experimental and analytical studies of buckling-restrained braces with various gusset connections," Engineering Structures, vol. 163, pp. 38 $50,2018$.

[7] R. Ozcelik and E. F. Erdil, "Pseudodynamic Test of a Deficient RC Frame strengthened with buckling restrained braces," Earthquake Spectra, vol. 35, no. 3, pp. 1163-1187, 2019.

[8] R. Ozcelik, Y. Dikiciasik, and E. F. Erdil, "The development of the buckling restrained braces with new end restrains," Journal of Constructional Steel Research, vol. 138, pp. 208-220, 2017.

[9] Y. L. Guo, J.-Z. Tong, X.-A. Wang, and P. Zhou, "Subassemblage tests and design of steel channels assembled buckling-restrained braces," Bulletin of Earthquake Engineering, vol. 16, no. 9, pp. 4191-4224, 2018. 
[10] M. B. Bozkurt and C. Topkaya, "Development of welded overlap core steel encased buckling restrained braces," Journal of Constructional Steel Research, vol. 127, pp. 151-164, 2016.

[11] R. Özçelik, "Buckling restrained braces," Pamukkale University Journal of Engineering Sciences, vol. 22, no. 3, pp. 160-170, 2016.

[12] Y.-L. Guo, J.-Z. Tong, X.-A. Wang, and B.-H. Zhang, "Subassemblage tests and numerical analyses of buckling-restrained braces under pre-compression," Engineering Structures, vol. 138, pp. 473-489, 2017.

[13] C.-C. Chou and S.-Y. Chen, "Subassemblage tests and finite element analyses of sandwiched buckling-restrained braces," Engineering Structures, vol. 32, no. 8, pp. 2108-2121, 2010.

[14] M. AlHamaydeh, F. Abed, and A. Mustapha, "Key parameters influencing performance and failure modes for BRBs using nonlinear FEA," Journal of Constructional Steel Research, vol. 116, pp. $1-18,2016$.

[15] H. Heidary-Torkamani and S. Maalek, "Conceptual numerical investigation of all-steel Tube in-Tube buckling restrained braces," Journal of Constructional Steel Research, vol. 139, pp. 220-235, 2017.

[16] C. Avci-Karatas, O. C. Celik, and S. Ozmen Eruslu, "Modeling of Buckling Restrained Braces (BRBs) using Full-Scale Experimental Data," KSCE Journal of Civil Engineering, vol. 23, no. 10, pp. 4431-4444, 2019.

[17] X.-Y. Cao, D.-C. Feng, G. Wu, and Y.-H. Zeng, "Reusing \& replacing performances of the AB-BRB with thin-walled concrete-infilled steel shells," Thin-Walled Structures, vol. 157, p. 107069, 2020.

[18] Z. Jiang, Y. Guo, B. Zhang, and X. Zhang, "Influence of design parameters of buckling restrained brace on its performance," Journal of Constructional Steel Research, vol. 105, pp. 139-150, 2015.

[19] ABAQUS Manual, Providence, RI, USA, "Abaqus Version 6.12-1 Documentation," 2012.

[20] E. Madenci, andY. O. Özkılıç,"Free vibration analysis of open cell FG porous beams: analytical, numerical and ANN approaches," Steel and Composite Structures, vol. 40, no. 2, pp. 157 $173,2021$.

[21] C. Aksoylu, Y. O. Özkılıç, and M. H. Arslan, "Damages on prefabricated concrete dapped-end purlins due to snow loads and a novel reinforcement detail," Engineering Structures, vol. 225, pp. $111225,2020$.

[22] C. Aksoylu, Y. O. Özkılıç, Ş. Yazman, L. Gemi and M. H. Arslan, "Experimental and Numerical Investigation of Load Bearing Capacity of Thinned End Precast Purlin Beams and Solution Proposals," Teknik Dergi, vol. 32, no. 3 p. 10823-10858, 2021.

[23] E. Madenci, Y. O. Özkılıç, and L. Gemi, "Theoretical investigation on static analysis of pultruded GFRP composite beams,"Akademik Platform Mühendislik ve Fen Bilimleri Dergisi, vol. 8, no. 3, pp. 483-490, 2020.

[24] L. Gemi, E. Madenci, and Y. O. Özkılıç, "Experimental, analytical and numerical investigation of pultruded GFRP composite beams infilled with hybrid FRP reinforced concrete,"Engineering Structures, vol. 244, pp. 112790, 2021. 
[25] Y. O. Özkılıç, "A comparative study on yield line mechanisms for four bolted extended end plated connection," Challenge Journal of Structural Mechanics, vol. 7, no. 3, pp. 93-106, 2021.

[26] Y. O. Özk1liç, "Investigation of the effects of bolt diameter and end-plate thickness on the capacity and failure modes of end-plated beamto-column connections," Research on Engineering Structures \& Materials, in-press, 2021.

[27] Y. O. Özkılıç, "A new replaceable fuse for moment resisting frames: Replaceable bolted reduced beam section connections," Steel and Composite Structures, vol. 35, no. 3, pp. 353-370, 2020.

[28] Y. O. Özkılıç, M. B. Bozkurt, and C. Topkaya, "Mid-spliced end-plated replaceable links for eccentrically braced frames," Engineering Structures, vol. 237, p. 112225, 2021.

[29] M. B. Bozkurt, S. Kazemzadeh Azad, and C. Topkaya, "Development of detachable replaceable links for eccentrically braced frames," Earthquake Engineering \& Structural Dynamics, vol. 48, no. 10, pp. 1134-1155, 2019.

[30] G. Della Corte, M. D'Aniello, and R. Landolfo, "Analytical and numerical study of plastic overstrength of shear links," Journal of Constructional Steel Research, vol. 82, pp. 19-32, 2013.

[31] Y. O. Özkılıç, "Experimental and numerical studies on replaceable links for eccentrically braced frames," Middle East Technical University, Doctoral Dissertation, Ankara, Turkey, 2020.

[32] P. W. Richards and C.-M. Uang, "Effect of flange width-thickness ratio on eccentrically braced frames link cyclic rotation capacity," Journal of Structural Engineering, vol. 131, no. 10, pp. 1546-1552, 2005.

[33] Y. O. Özkılıç, and C. Topkaya, "Extended end-plate connections for replaceable shear links," Engineering Structures, vol. 240, p. 112385, 2021.

[34] Y. O. Özkılıç, "Optimized stiffener detailing for shear links in eccentrically braced frames," Steel and Composite Structures, vol. 39, no. 1, pp. 35-50, 2021.

[35] L. Gemi, E. Madenci and Y. O. Özkılıç, "Çelik, Cam FRP ve hibrit donatılı betonarme kirişlerin eğilme performansının incelenmesi,"Düzce Üniversitesi Bilim ve Teknoloji Dergisi, vol. 8, no. 2 , pp. 1470-1483, 2020.

[36] M. B. Bozkurt, Y. O. Özkılıç,and C. Topkaya, "Investigation on connection details for welded overlap core steel encased buckling restrained braces," presented at the 13th International Congress on Advances in Civil Engineering, İzmir, Turkey, 2018.

[37] AISC. 341-16, Seismic provisions for structural steel buildings. 2016.

[38] Z. Yi, "Assessment Using FEA of the Influence of Detailing Parameters on Performance of Buckling Restrained Braces," Politehnica University, Msc, 2016. 